\title{
Regional and Temporal Population Structure of Pseudoperonospora cubensis in Michigan and Ontario
}

\author{
R. P. Naegele, L. M. Quesada-Ocampo, J. D. Kurjan, C. Saude, and M. K. Hausbeck
}

First, third, and fifth authors: Department of Plant, Soil and Microbial Sciences, Michigan State University, East Lansing; second author: Department of Plant Pathology, North Carolina State University, Raleigh; and fourth author: Canadian Tobacco Research Foundation, Tillonsburg, Ontario, Canada.

Accepted for publication 24 December 2015.

\begin{abstract}
Naegele, R. P., Quesada-Ocampo, L. M., Kurjan, J. D., Saude, C., and Hausbeck, M. K. 2016. Regional and temporal population structure of Pseudoperonospora cubensis in Michigan and Ontario. Phytopathology 106:372-379.

Cucurbit downy mildew (CDM), caused by the oomycete pathogen Pseudoperonospora cubensis, is a devastating disease that affects cucurbit species worldwide. This obligate, wind-dispersed pathogen does not overwinter in Michigan or other northern regions and new isolates can enter the state throughout the growing season. To evaluate the regional

and temporal population structure of $P$. cubensis, sporangia from CDM lesions were collected from cucurbit foliage grown in Michigan and Ontario field locations in 2011. Population structure and genetic diversity were assessed in 257 isolates using nine simple sequence repeat markers. Genetic diversity was high for isolates from Michigan and Canada $(0.6627$ and 0.6131 , respectively). Five genetic clusters were detected and changes in population structure varied by site and sampling date within a growing season. The Michigan and Canada populations were significantly differentiated, and a unique genetic cluster was detected in Michigan.
\end{abstract}

Cucurbit downy mildew (CDM), caused by the diploid oomycete plant pathogen Pseudoperonospora cubensis, is a foliar disease that can cause yield loss up to $100 \%$ in susceptible crops (Call et al. 2012; Holdsworth et al. 2014). Michigan, the number one producer of pickling cucumbers in the United States, produces over 45,000 acres of susceptible crops each year (Anonymous 2013b). The province of Ontario is the number one producer of greenhouse cucumbers in Canada with over 230 hectares grown annually (Anonymous 2012). Michigan and Canada produce cantaloupes, melons, pumpkins, and hard squashes, but cucumbers are the most susceptible and economically important host (Anonymous 2012, 2013a, 2013b; Lebeda and Widrlechner 2003).

Prior to 2004, P. cubensis could be managed through host resistance in cucumber that was introduced in the 1960s (Holmes et al. 2006; Savory et al. 2011). However in 2004, a CDM outbreak occurred in North Carolina (Holmes and Thomas 2009) and nearby states. In 2005, growers in Michigan and the eastern United States experienced a similar CDM outbreak (Granke and Hausbeck 2011). Since 2005, CDM has been an annual concern in the absence of effective host resistance, growers must rely on fungicide applications every 5 to 7 days depending on the presence of the disease (Granke et al. 2014). In Michigan, the estimated cost to protect pickling cucumbers from CDM is $\$ 6$ million annually (Granke et al. 2014; Savory et al. 2011). With the recent appearance of fungicide-resistant populations in several regions, including Michigan, growers face new challenges in limiting this destructive disease (Adams et al. 2014; Hausbeck and Linderman 2014; Lebeda and Cohen 2011; Moss 1987; Urban and Lebeda 2007; Wang et al. 2014; Zhang et al. 2008).

Corresponding author: M. K. Hausbeck; E-mail address: hausbec1@msu.edu

*The $\boldsymbol{e}$-Xtra logo stands for "electronic extra" and indicates that two supplementary tables are published online.

http://dx.doi.org/10.1094/PHYTO-02-15-0043-R

(C) 2016 The American Phytopathological Society
Inoculum arrives to Michigan fields each year from southern states or greenhouses where the pathogen overwinters on living hosts (Savory et al. 2011). Oospores have not been detected in the soil or host tissue in the United States and are not considered a source of inoculum (Quesada-Ocampo et al. 2012). Recent studies indicate that the pathogen can also contaminate seed (Cohen et al. 2014) and infect wild cucurbits (Runge and Thines 2009; Wallace et al. 2014). Sporangia can move via air currents up to $1,000 \mathrm{~km}$, with viability limited by unfavorable environmental conditions (Kanetis et al. 2010; Ojiambo and Holmes 2011). Previous population studies revealed high genetic diversity in $P$. cubensis (Lebeda et al. 2013; Quesada-Ocampo et al. 2012; Sarris et al. 2009; Urban and Lebeda 2007). In a global analysis of $P$. cubensis population structure by Quesada-Ocampo et al. (2012), six genetic clusters were detected. Approximately $50 \%$ of the isolates evaluated had membership in a single cluster, while the remaining isolates were admixed (membership in more than one cluster). The Michigan isolates evaluated had significant genetic differentiation from 15 of the other states evaluated including South and North Carolina, and Indiana, but were not different from Canadian populations (QuesadaOcampo et al. 2012). However, the lack of regional differences detected could, in part, be due to limited samplings from Michigan and Canada. The study by Quesada-Ocampo et al. (2012) also noted higher genetic diversity of $P$. cubensis isolates in North Carolina and Florida. Population diversity in the southeastern United States may be driven by greater regional host availability and proximity to overwintering regions (Holmes et al. 2015).

While initial studies have provided an overview of the large-scale genetic structure of $P$. cubensis in the United States across several years, information of population structuring at the field or regional level within a growing season is lacking. Temporal changes in population structure may occur as plants age, environmental conditions change, and fungicides are applied. P. cubensis has a prolific asexual phase and can rapidly spread throughout a field. In field studies in the Czech Republic, temporal changes in the pathogen population virulence were detected between 2001 and 2010 (Lebeda et al. 2013). In other wind-dispersed pathogens, such as Magnaporthe 
oryzae on rice, significant changes in annual population structure have been detected (Lara-Álvarez et al. 2010). Temporal changes within a single growing season in CDM populations will have an impact on developing effective management strategies; thus, in this study we aimed to evaluate (i) regional differences in CDM population structure among cucurbit fields in Michigan and Ontario and (ii) temporal changes in population structure in Michigan cucumber fields during a single growing season.

\section{MATERIALS AND METHODS}

Plant samples. In 2011, 25 symptomatic cucumber leaves, cultivars Eureka and Vlaspik, were collected from two previously described field sites in Berrien and Allegan counties in Michigan (Granke and Hausbeck 2011; Granke et al. 2014) and an additional three field sites (MSU Plant Pathology Research Farm in East Lansing, MI, Ingham County; MSU Muck Soils Research Farm in Laingsburg, MI, Shiawassee County; and the MSU Saginaw Valley Research and Extension Center in Frankenmuth, MI, Saginaw County) for each sampling date. Symptomatic leaves were returned to the laboratory for CDM verification. Field sites represented five counties across Michigan. Samples were collected from each field on two sampling dates, August and September 2011 with the exception of Ingham County, which was only sampled in September. Downy mildew developed late in Michigan in 2011 and the earliest disease confirmation was in early August. In Canada, symptomatic leaves were collected from 12 fields of cucurbits (cantaloupe, spaghetti squash, bottle gourd, and cucumber) in Ontario in 2011. All samples were examined in the laboratory using a microscope $(200 \times)$ and $P$. cubensis was confirmed using morphological characteristics (Zitter et al. 1996). Sporangia were removed from one individual lesion per leaf by pipetting $200 \mu \mathrm{l}$ of sterile $\mathrm{ddH}_{2} \mathrm{O}$ water onto a lesion, gently dislodging the sporangia with the end of the pipette tip, and collecting the liquid. Sporangia collected from an individual lesion are hereafter referred to as an isolate.

Molecular analyses. Each individual sample was aliquot into a single well of a 96 -well plate and heated to $96^{\circ} \mathrm{C}$ for 15 min to promote cell lysis as described by Calmin et al. (2007). PCR was performed on each sample using previously published $P$. cubensis primers for the beta tubulin gene for species confirmation (Quesada-Ocampo et al. 2012). Reactions were performed in $20-\mu$ l total volume and contained $1 \mu$ of lysed cell supernatant, and $0.40 \mu \mathrm{l}$ of $1 \times$ GoTaq (Promega Corporation, Madison, WI), $1.25 \mu \mathrm{l}$ of $25 \mu \mathrm{M} \mathrm{MgCl}_{2}, 0.50 \mu \mathrm{l}$ of $10 \mu \mathrm{M}$ dNTPs, $0.04 \mu \mathrm{l}$ of bovine serum albumin, $1.25 \mu \mathrm{l}$ of $0.01 \%$ DMSO, $5.0 \mu \mathrm{l}$ of $5 \times$ GoTaq buffer, and $1.00 \mu \mathrm{l}$ each of $10 \mu \mathrm{M}$ forward and reverse primers (Integrated DNA Technologies, Inc.), with 8.56 $\mu \mathrm{l}$ of $\mathrm{ddH}_{2} \mathrm{O}$. PCR assays were performed in a programmable thermal cycler (Eppendorf, Westbury, NY) using the following program: initial denaturation, $94^{\circ} \mathrm{C}(3 \mathrm{~min})$ followed by 40 cycles at $94^{\circ} \mathrm{C}(30 \mathrm{~s}), 60^{\circ} \mathrm{C}(30 \mathrm{~s})$, and $72^{\circ} \mathrm{C}(1 \mathrm{~min})$, and a final extension step of $10 \mathrm{~min}$ at $72^{\circ} \mathrm{C}$. PCR products were analyzed by electrophoresis in 4\% (wt/vol) agarose gel in $1 \times$ Tris-borateEDTA buffer, stained with ethidium bromide $(5 \mu \mathrm{g} / \mathrm{ml})$ for visualization, and compared with a 100-bp ladder (Invitrogen Life Technologies, Burlington, Canada) to determine amplicon sizes. Samples that contained a band of the expected 400-bp size were retained; all other samples were removed from analyses. Forty-nine primers, developed from regions flanking simple sequence repeats (SSRs) in the draft genome sequence of $P$. cubensis, were evaluated against a subset of eight individuals from the population to identify polymorphic markers (Supplementary Table S1) using the same PCR conditions previously described. SSR markers identified as polymorphic in the population were used for population structure analyses (Table 1). The sequenced genotype MSU-1 (Tian et al. 2011) was included as a positive control for each 96-well plate.

Genetic diversity and population structure. Population structure was evaluated in the software STRUCTURE (v2.3.4) using the identified polymorphic markers (Pritchard et al. 2000) (Table 1, Supplementary Table S2). The number of genetic clusters was determined empirically using the methods described by Evanno et al. (2005). In brief, the log likelihood was compared for three independent runs at each estimated number of genetic clusters $(\mathrm{k})$ for $\mathrm{k} 1$ to 20 , using the admixture model with correlated allele frequencies with 500,000 MCMC chains and a burnin of 300,000. Visualization of the resulting $\mathrm{Q}$ (proportion of membership based on a 0 to 1 scale) of the population was sorted by field, country, county, and date using the population sorting tool (PST) in R [J. J. Morrice, $\mathrm{R}$ Development Core Team 2012]). Individuals with $\mathrm{Q} \geq 0.6 \mathrm{mem}-$ bership in a single subpopulation were labeled as such. Individuals with $\mathrm{Q}<0.6$ membership in a single subpopulation were considered admixed. Genetic diversity (calculated as the level of gene diversity) was estimated using Powermarker v3.25 (Liu and Muse 2005) and significance at each locus was determined with 1,000 permutations using the exact test; overall genetic diversity was estimated using the Mantel test as implemented in Powermarker. Significance of population structure within predefined categories was estimated using the population differentiation test implemented in Powermarker. Significance of pairwise Fst differentiation was based on 2.5 and $97.5 \%$ confidence intervals $(P=0.05)$ based on 1,000 bootstrap replications. Deviation from Hardy-Weinberg equilibrium (HWE) was evaluated for the population using the $\chi^{2}$ test, Fischer's exact test, and likelihood ratio test implemented within Powermarker. The inbreeding coefficient $\left(\mathrm{F}_{\mathrm{SI}}\right)$ was calculated using Powermarker. Marker pairwise disequilibrium linkage was evaluated for combinations of markers using the $\chi^{2}$ test and Fischer's exact test, and multiple allele D' implemented within Powermarker. The genotype accumulation based on marker number was estimated using the POPPR package v2.0 implemented in R (Kamvar et al. 2014, 2015). The index of association $\left(\mathrm{I}_{\mathrm{A}}\right)$ for Michigan and Canada was

TABLE 1. Polymorphic markers used for screening 257 Pseudoperonospora cubensis isolates

\begin{tabular}{|c|c|c|c|c|c|c|c|}
\hline $\mathrm{Name}^{\mathrm{w}}$ & SSR & Forward primer & Reverse primer & $\begin{array}{l}\text { Expected } \\
\text { size (bp) }\end{array}$ & $\begin{array}{l}\text { Number } \\
\text { of alleles }\end{array}$ & $\mathrm{GD}^{\mathrm{y}}$ & $\mathrm{PIC}^{\mathrm{z}}$ \\
\hline 1_1 & (TGC)4 & GTGGCTGGAGGAAGCAGTAG & CATGTTTCCCAATCCCCCGA & 201 & 12 & 0.5866 & 0.5299 \\
\hline 1_4 & (AGCA) 3 & AACTAGGCTTGGTCTCGCAC & GCACGAGCACCAAATCGATC & 256 & 15 & 0.7383 & 0.7021 \\
\hline 1_15 & $(\mathrm{AAAG}) 3$ & GACCAAAGTTCGCGAATCGG & GAAGTCGGGCTACTACGACG & 282 & 17 & 0.7423 & 0.7094 \\
\hline 1_20 & (CTC) 4 & TTTAGGGGAACACGTGCCTC & TACCTTCAACAGTGCGTGCA & 227 & 6 & 0.4456 & 0.3637 \\
\hline $1 \_24$ & (TCG) 4 & GCGATCCAGTGCATCGACTA & CTCTGCCCACGTGTACGG & 246 & 9 & 0.7232 & 0.6811 \\
\hline $1 \_25$ & (CAA) 4 & TGTTCATCTCGTGGCAGTCC & GTCTTCAGCGTCCACAGTCA & 294 & 7 & 0.548 & 0.4571 \\
\hline
\end{tabular}

${ }^{\mathrm{w}}$ Marker designation based off of Supplementary Table S1.

${ }^{x}$ Number of alleles detected within the population.

${ }^{y}$ Genetic diversity (GD) of each marker within the population

${ }^{\mathrm{z}}$ Polymorphism information content (PIC) of each marker within the population. 
estimated using POPPR, and for the total population using 999 permutations.

\section{RESULTS}

Two hundred fifty-seven isolates, 155 from Michigan and 102 from Ontario, were successfully used for SSR amplification and population analyses. Overall, 49 SSR markers were evaluated for polymorphism in the population. However, most markers $(82 \%)$ evaluated showed unspecific amplification, did not amplify, or were not polymorphic in the subpopulation evaluated. Nine markers consistently generated an amplification product, were polymorphic across the entire population, and were used for further analyses (Table 1). The genotype accumulation curve reached $90 \%$ of the multilocus genotypes and approached saturation with eight markers. To maintain consistency during genotyping, for each plate, the band size obtained for each SSR amplified in a sample was normalized to the band size produced by the control isolate MSU-1. A total of 100 alleles were detected in all nine SSRs, with an average allele diversity of 11.11 per SSR marker. The population significantly differed from HWE according to all three tests. Multi-allelic D' for pairs of markers ranged from 0.1348 to 0.3882 . $\chi^{2}$ and Fischer's exact test $P$ values were significantly different from the null hypothesis assuming HWE and no linkage disequilibrium for each combination of markers, suggesting the presence of a clonal population. The Inbreeding coefficient (f) was greater than 0.8 for each marker, indicating a heterozygote deficit in the population. Analyses using Powermarker $\mathrm{v} 3.25$ indicated that the mean genetic diversity for the population was 0.6868 and the mean polymorphism information content (PIC) was 0.6392 . Individual marker PIC ranged from 0.36 to 0.86 (Table 1 ). The $\mathrm{I}_{\mathrm{A}}$ of the population was 0.1003 , indicating association among alleles. The software STRUCTURE identified five genetic clusters in the population $(\mathrm{Ln}=-5,200.8$, lambda $=0.5075)$. Differences in clusters were great to very great according to the population differentiation guidelines suggested by Hartl and Clark (2007) and were as follows: Fst 1 to 5: 0.1204, 0.2274, 0.3226, 0.5540, and 0.3325 . Two hundred thirty-six isolates belonged to a discrete cluster (membership was $\geq 0.60$ ), while 26 individuals $(10 \%)$ with $<0.60$ membership were classified as admixed. When isolates were grouped into predefined categories of field, date, country, host, and year,

TABLE 2. Genetic diversity of Pseudoperonospora cubensis isolates

\begin{tabular}{llcccc}
\hline \multirow{2}{*}{ Category } & County & $\begin{array}{c}\text { Number of } \\
\text { individuals }^{\mathrm{y}}\end{array}$ & & \multicolumn{3}{c}{ Genetic diversity } \\
\cline { 5 - 6 } Month & & - & - & 0.66 & 0.68 \\
Michigan & & 155 & 0.66 & 0.65 & 0.65 \\
& Allegan & 37 & 0.53 & 0.45 & 0.52 \\
& Berrien & 24 & 0.58 & 0.49 & 0.59 \\
& Ingham & 9 & 0.37 & - & 0.37 \\
& Shiawassee & 31 & 0.61 & 0.61 & 0.47 \\
& Saginaw & 54 & 0.55 & 0.54 & 0.52 \\
Ontario & & 102 & 0.65 & 0.57 & 0.65 \\
\hline
\end{tabular}

y Number of individuals in each category used for analyses.

z Genetic diversity of the population for each category. significant differentiation was detected. The predefined categories explained 5 to $81 \%$ of the differentiation detected.

The PIC and genetic diversity of isolates from Ontario was 0.5978 and 0.6515 , respectively, while the PIC and genetic diversity of isolates from Michigan was 0.6131 and 0.6627 , respectively, regardless of host (Table 2). The $\mathrm{I}_{\mathrm{A}}$ was lower for Michigan (0.0915) than Canada (0.2166). Michigan and Ontario had significant population differentiation (0.081) according to Fst values. Bayesian clustering analysis indicated that all genetic clusters found in Ontario were also present in Michigan and that Michigan had a single unique genetic cluster (dark blue) not present in Ontario (Fig. 1). In Michigan, the light blue cluster had poor representation compared with Ontario, while the green cluster had poor representation in Ontario compared with Michigan (Figs. 1 and 2).

When isolates were grouped by country and month of collection, significant differences were detected according to Fst values (Table 3). Isolates collected in Ontario in August were significantly differentiated from isolates collected in Michigan (August and September) and isolates collected in September in Ontario. Genetic diversity was higher in Michigan (0.65) than Ontario (0.57) in August (Table 2). Genetic diversity did not change from August to September in Michigan, but was higher in September than August for Ontario. Bayesian clustering analysis detected only one genetic cluster in Ontario in August, while four clusters were detected in Michigan (Fig. 1). The single cluster found in Ontario was not found in Michigan in August. No differences in population structure were detected in Michigan from August to September. Significant differences in population structure were also detected when isolates collected in August were compared with isolates collected in September, regardless of which country they had originated.

When isolates were grouped by county regardless of month, significant differences in Fst values were detected between Allegan County and Ingham and Saginaw counties, but not Shiawassee nor Berrien counties (Table 4). Allegan, Berrien, Ingham, and Saginaw counties were all significantly differentiated from isolates collected in Ontario (Table 4, Fig. 3). Genetic diversity among counties in Michigan varied from 0.37 to 0.61 (Table 2). The highest genetic diversity in Michigan was detected in Shiawassee County. Ontario had a higher genetic diversity than any single county in Michigan (Table 2). When isolates were grouped by county and month, significant differences in population structure between August and September were detected in Michigan according to Fst values (Table 5). In August, significant differences in population structure were detected between Allegan and Saginaw, but not Allegan and Berrien or Allegan/Berrien and Shiawassee counties. Bayesian clustering determined that in Allegan and Saginaw, the yellow and purple clusters, respectively, found in the August population were no longer evident in the September sampling (Fig. 3). While in Berrien, an additional cluster (light blue) was detected in the September sampling. In September, significant differences in population structure were detected between Berrien or Allegan and Saginaw and Ingham counties. No changes in population structure from August to September were detected within fields in Allegan, Berrien, or Shiawassee counties in Michigan, but were present among fields in Ontario and Saginaw
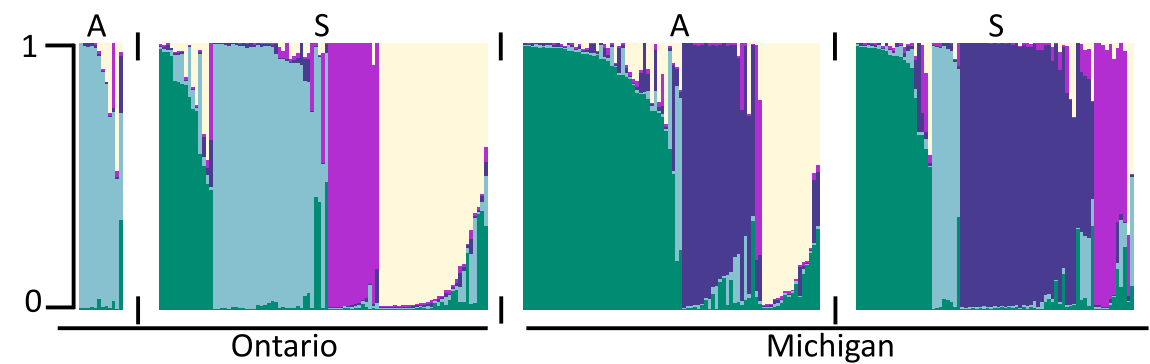

Fig. 1. Population structure of Pseudoperonospora cubensis isolates grouped by collection date in August (A) and September (S) for Michigan and Ontario. 
counties in Michigan (Table 5). Changes in genetic diversity from August to September varied by county. Allegan and Berrien had higher genetic diversity in September compared with August. Shiawassee and Saginaw counties had lower or similar genetic diversity from August to September (Table 2).

Genetic diversity in fields varied greatly from 0.37 to 0.61 in Michigan and 0.23 to 0.59 in Ontario (Table 6) using all isolates. Five of the fields evaluated had PIC values greater than 0.5 (Table 6). The MSU Muck Soils Research Farm (Shiawassee County) had the highest genetic diversity, and the MSU Plant Pathology Farm (Ingham County) had the lowest genetic diversity. In Ontario, the field from Alymer had the highest genetic diversity, while the Mucks Crop Station had the lowest diversity. When individual fields were compared between Michigan and Ontario, 5 to $55 \%$ of the differentiation was explained by the field designation (Table 7). Most fields evaluated were significantly differentiated from the others for both Michigan and Ontario according to Fst values. Most fields evaluated had a single genetic cluster as the dominant genotype (Fig. 4) according to Bayesian clustering. The dark purple cluster was only found in Michigan in the Saginaw Valley Research Station and two individuals at the MSU Muck Farm. No correlation was detected between significant differentiation of fields and the country of origin.

Most isolates analyzed in this study were from cucumber (249 individuals); however, two isolates from cantaloupe, and 10 from spaghetti squash were also included. Isolates from cucumber and spaghetti squash were significantly differentiated from each other (0.81). All genetic clusters were represented in the cucumber isolates, while only the purple cluster was detected in the isolates from spaghetti squash (Fig. 5). Cucumber isolates had the highest PIC and genetic diversity, 0.64 and 0.69 , respectively, while spaghetti squash isolates had a PIC and genetic diversity of 0.20 and 0.23 , respectively.

\section{DISCUSSION}

$P$. cubensis is a wind-dispersed, foliar pathogen characterized by prolific asexual reproduction and dissemination throughout the growing season. Asexual reproduction allows for rapid propagation of selected genotypes, but new isolates may arrive on wind currents.

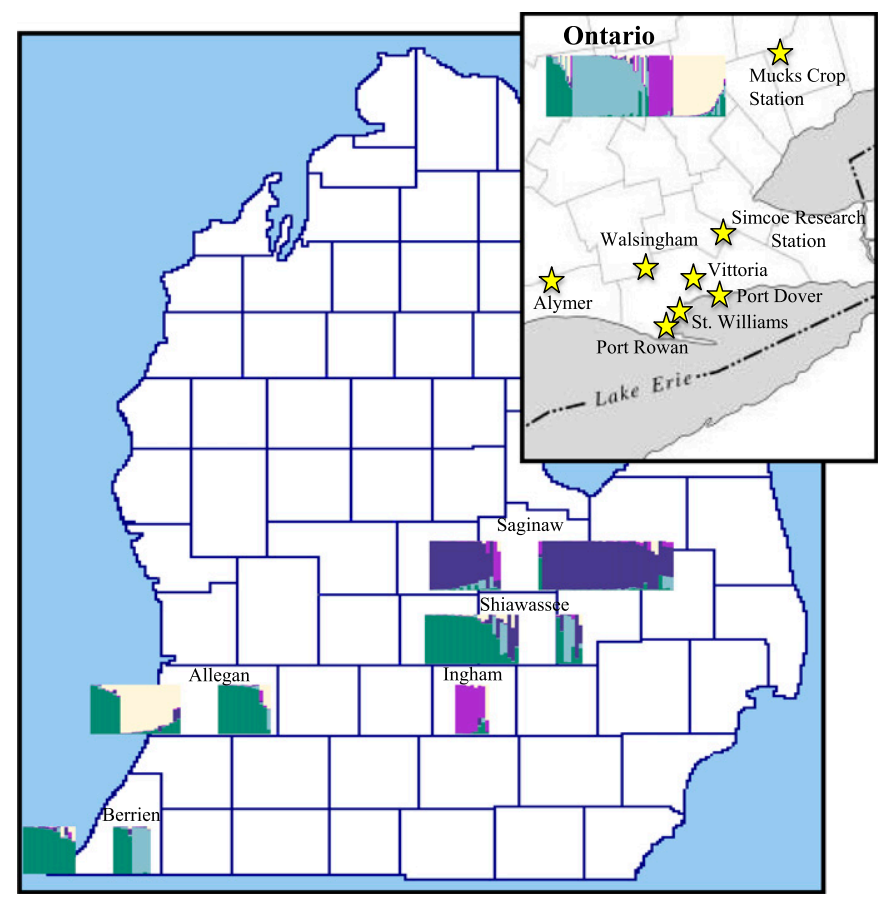

Fig. 2. Population structure of Pseudoperonospora cubensis isolates in Michigan and Ontario.
Intensive management strategies, large acreages of monoculture, and varying environmental conditions put selective pressures on burgeoning insect or pathogen populations, which can alter the dominant genotype over time (Franck and Timm 2010; McDonald et al. 1989).

Previous studies have shown that global and regional population structure is present in $P$. cubensis populations, and that populations can change annually (Cespedes-Sanchez et al. 2014; Lebeda et al. 2013; Quesada-Ocampo et al. 2012; Sarris et al. 2009). These population studies have looked at spatial differences among isolates, but have had insufficient sampling to detect changes in the seasonal population structure. In temperate regions, crop pathogens are subjected to long periods without a living host. In obligate, winddispersed pathogens such as rusts and downy mildews, the pathogen re-enters these regions annually from overwintering sites (Savory et al. 2011; Sharma-Poudyal et al. 2014). Identifying temporal changes in population structure can give insight into the migration of isolates, and environmental selection of genotypes (Xhaard et al. 2012). If isolates enter the state annually and no new individuals arrive during the growing season, a founder effect would be observed each year (Halkett et al. 2010; Rivera et al. 2015; Xhaard et al. 2012). This would result in a population with low allelic diversity and high genetic similarity. In this study, the overall PIC in the population was high (0.64), suggesting the pathogen is highly heterozygous for the markers evaluated, and that multiple alleles were present for each locus. Strong linkage-disequilibrium was observed among markers, consistent with the presence of a clonal population. Based on these data it is unlikely that a single founder event is directing the population structure in these regions. If new genotypes continually enter the state and become established, it is likely the population diversity would increase during the growing season and show temporal structure. Similarly in our study, genetic diversity of $P$. cubensis increased from August to September suggesting new alleles are appearing during this time in Ontario and most fields evaluated in Michigan. As new isolates gradually migrate into new regions, the genetic differentiation among locations is greatly reduced (Barrès et al. 2008; Hartl and Clark 2007). In this study, variation in genetic diversity and population structure was evident among sites and between sampling dates within and among fields. This variation was low, however, consistent with the gradual migration of isolates between Ontario and Michigan. Greater sampling within fields across dates and years may reveal a greater level of migration however. Five genetic clusters were detected, and isolate genotypes were significantly differentiated when they were grouped by the predefined categories of location or time. A high level of inbreeding was also observed across the entire population

TABLE 3. Genetic differentiation of Pseudoperonospora cubensis isolates from Ontario and Michigan grouped by month ${ }^{\mathrm{z}}$

\begin{tabular}{lccc}
\hline & $\begin{array}{c}\text { Ontario_ } \\
\text { August }\end{array}$ & $\begin{array}{c}\text { Ontario_ } \\
\text { September }\end{array}$ & $\begin{array}{c}\text { Michigan_ } \\
\text { August }\end{array}$ \\
\hline Ontario_August & - & & \\
Ontario_September & $0.26^{*}$ & - & \\
Michigan_August & $0.29^{*}$ & $0.09^{*}$ & - \\
Michigan_September & $0.28^{*}$ & $0.08^{*}$ & 0.04 \\
\hline
\end{tabular}

$\mathrm{z} *$ Indicates a significant Fst value.

TABLE 4. Genetic differentiation of Pseudoperonospora cubensis isolates from Ontario and Michigan grouped by county ${ }^{\mathrm{z}}$

\begin{tabular}{lccccc}
\hline County & Allegan & Berrien & Ingham & Saginaw & Shiawassee \\
\hline Allegan & - & & & & \\
Berrien & 0.11 & - & & & \\
Ingham & $0.37^{*}$ & $0.35^{*}$ & - & & \\
Saginaw & $0.26^{*}$ & $0.17^{*}$ & $0.45^{*}$ & - & \\
Shiawassee & 0.12 & 0.10 & $0.41^{*}$ & $0.16^{*}$ & - \\
Ontario & $0.18^{*}$ & $0.18^{*}$ & $0.57^{*}$ & $0.20^{*}$ & $0.15^{*}$ \\
\hline
\end{tabular}

$\mathrm{z} *$ Indicates a significant Fst value. 
consistent with the presence of subpopulation structure. Approximately $10 \%$ of the isolates were admixed, compared with the $50 \%$ detected by Quesada-Ocampo et al. (2012). Similarly, no admixture was found among $P$. cubensis populations from Israel, Asia and the Czech Republic when using microsatellite markers to detect structure (Polat et al. 2014). This is likely due to differences in sampling and molecular markers used or could be the result of limited recombination among clusters. Quesada-Ocampo et al. (2012) evaluated single nucleotide polymorphism markers in seven genes and isolates from multiple host species, countries, and years. While the present study included three hosts and two countries, the purpose was to evaluate regional changes in population structure using SSR markers.

In Michigan, changes in population structure were evident, but not significant, between August and September for most counties
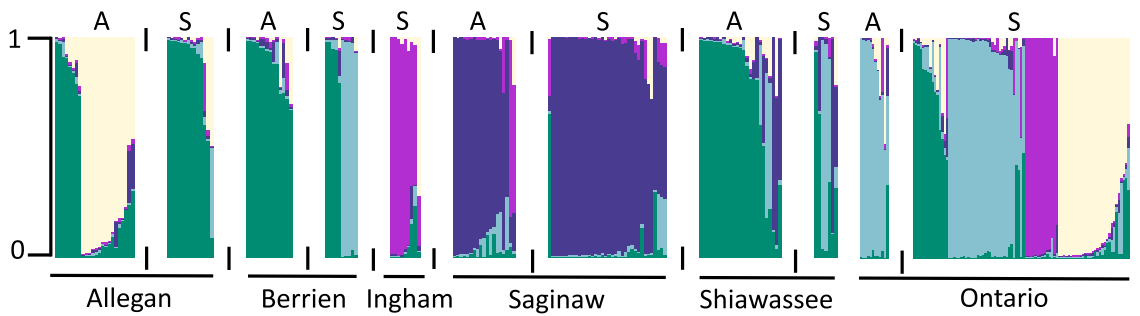

Fig. 3. Population structure of Pseudoperonospora cubensis isolates grouped by collection date in August (A) and September (S) for Michigan counties (Allegan, Berrien, Ingham, Saginaw, and Shiawasee) and Ontario.

TABLE 5. Genetic differentiation of Pseudoperonospora cubensis isolates from Ontario and Michigan grouped by county and month ${ }^{\circ}$

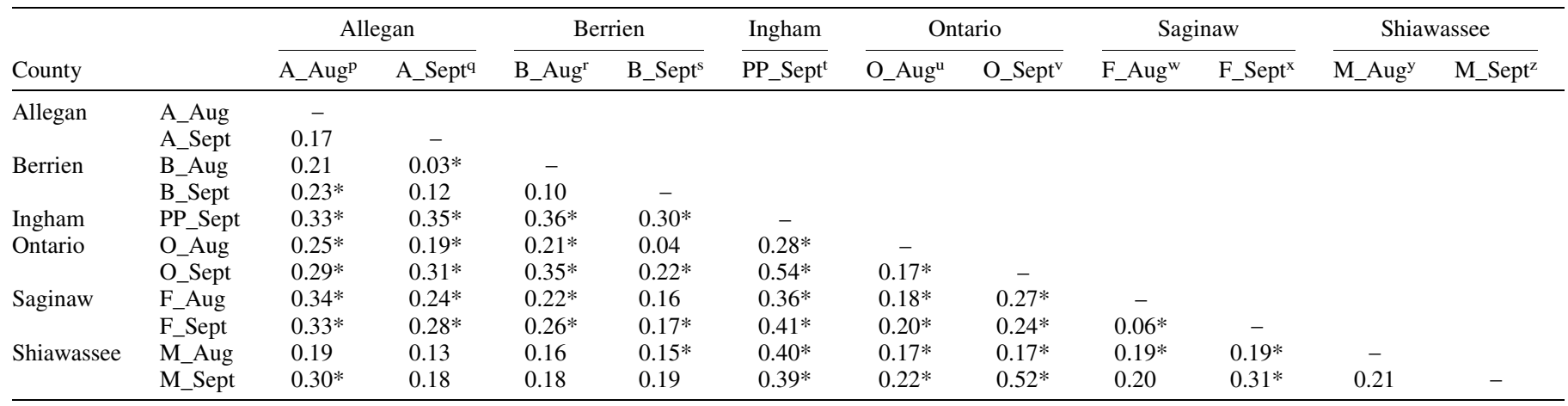

o $*$ Indicates a significant Fst value.

p P. cubensis isolates collected from Allegan County in August.

q P. cubensis isolates collected from Allegan County in September.

${ }^{\mathrm{r}}$ P. cubensis isolates collected from Berrien County in August.

s P. cubensis isolates collected from Berrien County in September.

${ }^{t}$ P. cubensis isolates collected from the Plant Pathology farm in Ingham County in September.

"P. cubensis isolates collected from Ontario in August.

${ }^{v} P$. cubensis isolates collected from Ontario in September.

${ }^{w} P$. cubensis isolates collected from the Saginaw Valley Research Station in Saginaw County in August.

${ }^{x}$ P. cubensis isolates collected from the Saginaw Valley Research Station in Saginaw County in September.

y $P$. cubensis isolates collected from the Muck Research Station in Shiawassee County in August.

${ }^{\mathrm{z}}$ P. cubensis isolates collected from the Muck Research Station in Shiawassee County in September.

TABLE 6. Genetic diversity of Pseudoperonospora cubensis isolates from individual fields in Ontario and Michigan

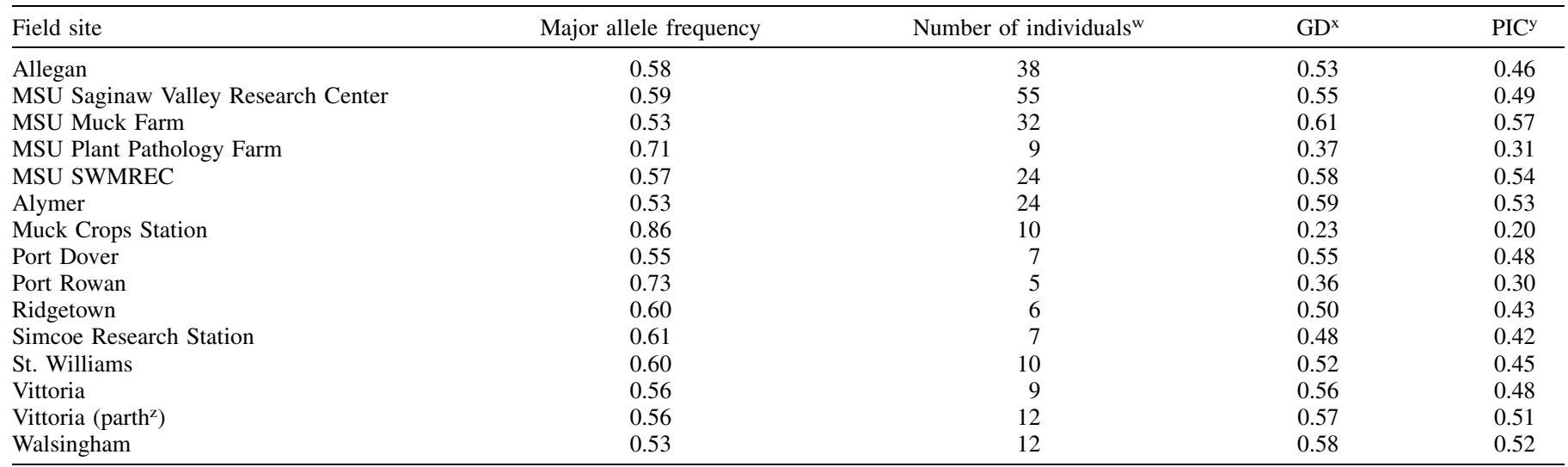

${ }^{w}$ Number of individuals in each category used for analyses.

${ }^{x}$ Genetic diversity (GD) of the population for each category.

y Polymorphism information content (PIC) for each category.

${ }^{\mathrm{z}}$ Collected from a field of parthenocarpic cucumbers. 
and fields. The limited changes may be due to sampling size or marker resolution, and not stagnancy in the population. Previous studies that combined isolates from multiple years have suggested that Michigan and Canada have similarly structured genetic populations of $P$. cubensis (Quesada-Ocampo et al. 2012). In this study, significant differentiation was detected between the two countries when population structure was examined in more detail within a year. However, only $8 \%$ of the genetic differentiation

TABLE 7. Genetic differentiation of Pseudoperonospora cubensis isolates from Ontario and Michigan grouped by fields ${ }^{1}$

\begin{tabular}{|c|c|c|c|c|c|c|c|c|c|c|c|c|c|c|}
\hline Field site & $\mathrm{AL}^{\mathrm{m}}$ & $\mathrm{ALY}^{\mathrm{n}}$ & $\mathrm{B} \& \mathrm{~B}^{\circ}$ & $\mathrm{M}^{\mathrm{p}}$ & $\mathrm{MC}^{\mathrm{q}}$ & $\mathrm{PP}^{\mathrm{r}}$ & $\mathrm{PD}^{\mathrm{s}}$ & $\mathrm{PR}^{\mathrm{t}}$ & $\mathrm{R}^{\mathrm{u}}$ & $S^{v}$ & $\mathrm{SW}^{\mathrm{w}}$ & SWMREC $^{\mathrm{x}}$ & $V^{y}$ & $\mathrm{VP}^{\mathrm{z}}$ \\
\hline Allegan & - & & & & & & & & & & & & & \\
\hline Alymer & $0.18 *$ & - & & & & & & & & & & & & \\
\hline B\&B Farm & $0.26^{*}$ & $0.20 *$ & - & & & & & & & & & & & \\
\hline Muck & 0.12 & $0.17 *$ & $0.16^{*}$ & - & & & & & & & & & & \\
\hline Muck Crops & $0.51 *$ & $0.41 *$ & $0.55^{*}$ & $0.50 *$ & - & & & & & & & & & \\
\hline Plant Path & $0.37 *$ & $0.32 *$ & $0.45^{*}$ & $0.41 *$ & 0.22 & - & & & & & & & & \\
\hline Port Dover & $0.19 *$ & 0.13 & $0.27 *$ & $0.21 *$ & $0.45^{*}$ & $0.31 *$ & - & & & & & & & \\
\hline Port Rowan & $0.48^{*}$ & $0.38 *$ & $0.54^{*}$ & $0.48 *$ & $0.07 *$ & 0.16 & $0.33 *$ & - & & & & & & \\
\hline Ridgetown & $0.28 *$ & 0.15 & $0.36^{*}$ & $0.32 *$ & $0.42 *$ & $0.26 *$ & $0.19 *$ & $0.35^{*}$ & - & & & & & \\
\hline Simcoe & $0.33 *$ & 0.17 & $0.33^{*}$ & $0.27 *$ & $0.48 *$ & $0.38 *$ & 0.10 & $0.32 *$ & $0.20 *$ & - & & & & \\
\hline St. Williams & 0.17 & 0.15 & $0.33^{*}$ & $0.24 *$ & $0.46^{*}$ & $0.33 *$ & 0.08 & $0.36^{*}$ & $0.22 *$ & $0.24 *$ & - & & & \\
\hline SWMREC & 0.11 & $0.14 *$ & $0.18^{*}$ & 0.10 & $0.46^{*}$ & $0.35^{*}$ & $0.19 *$ & $0.39^{*}$ & $0.28 *$ & 0.18 & $0.23 *$ & - & & \\
\hline Vittoria & 0.16 & $0.15^{*}$ & $0.27 *$ & $0.22 *$ & $0.42 *$ & $0.29 *$ & 0.10 & $0.33^{*}$ & $0.21 *$ & $0.23 *$ & 0.09 & $0.23 *$ & - & \\
\hline Vittoria $^{z}$ & 0.12 & 0.11 & $0.22 *$ & $0.19^{*}$ & $0.40^{*}$ & $0.27 *$ & 0.08 & $0.33^{*}$ & $0.19 *$ & $0.21 *$ & 0.07 & $0.19^{*}$ & 0.06 & - \\
\hline Walsingham & $0.23 *$ & 0.05 & $0.21 *$ & $0.19 *$ & $0.44 *$ & $0.33^{*}$ & 0.11 & $0.35^{*}$ & 0.14 & 0.06 & 0.19 & 0.12 & $0.22 *$ & $0.17 *$ \\
\hline
\end{tabular}

$1 *$ indicates a significant Fst value.

${ }^{\mathrm{m}}$ P. cubensis isolates collected from Allegan County, Michigan.

${ }^{n} P$. cubensis isolates collected from Alymer in Ontario.

o P. cubensis isolates collected in Saginaw County, Michigan.

p P. cubensis isolates collected in Shiawassee County, Michigan.

q P. cubensis isolates collected from the Mucks Crop Station in Ontario.

r $P$. cubensis isolates collected from Ingham County, Michigan.

s $P$. cubensis isolates collected from Port Dover in Ontario.

t $P$. cubensis isolates collected from Port Rowan in Ontario.

u $P$. cubensis isolates collected from Ridgetown in Ontario.

v $P$. cubensis isolates collected from the Simcoe Research Station in Ontario.

${ }^{w} P$. cubensis isolates collected from St. Williams in Ontario.

${ }^{x}$ P. cubensis isolates collected from Berrien County, Michigan.

y $P$. cubensis isolates collected from Vittoria in Ontario.

${ }^{\mathrm{z}} P$. cubensis isolates collected from parthenocarpic cucumbers in Vittoria in Ontario.

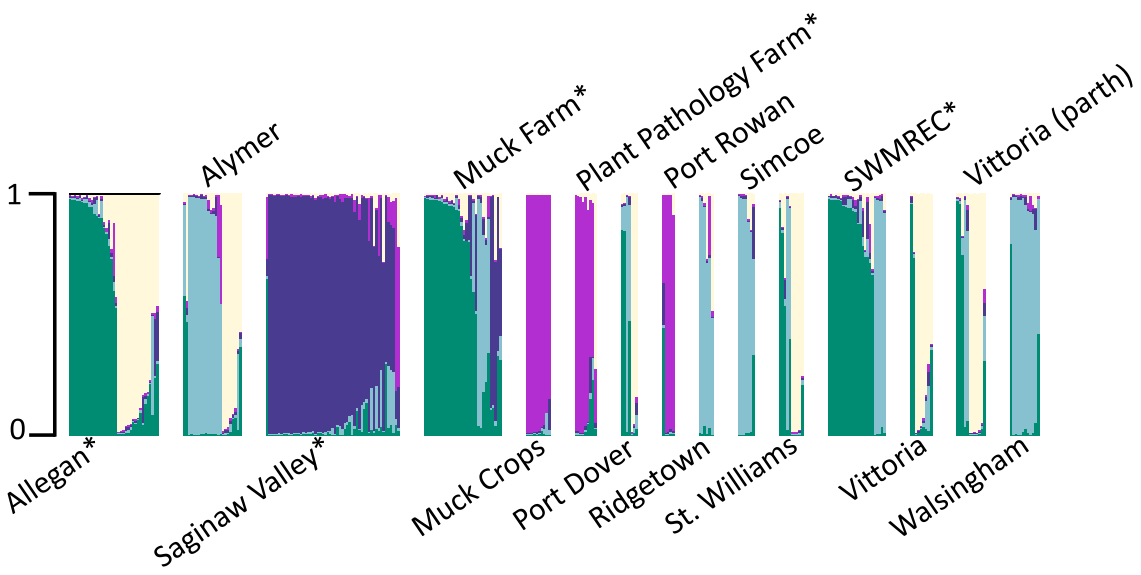

Fig. 4. Population structure of Pseudoperonospora cubensis isolates grouped by collection field for Michigan (denoted by an *) and Ontario.

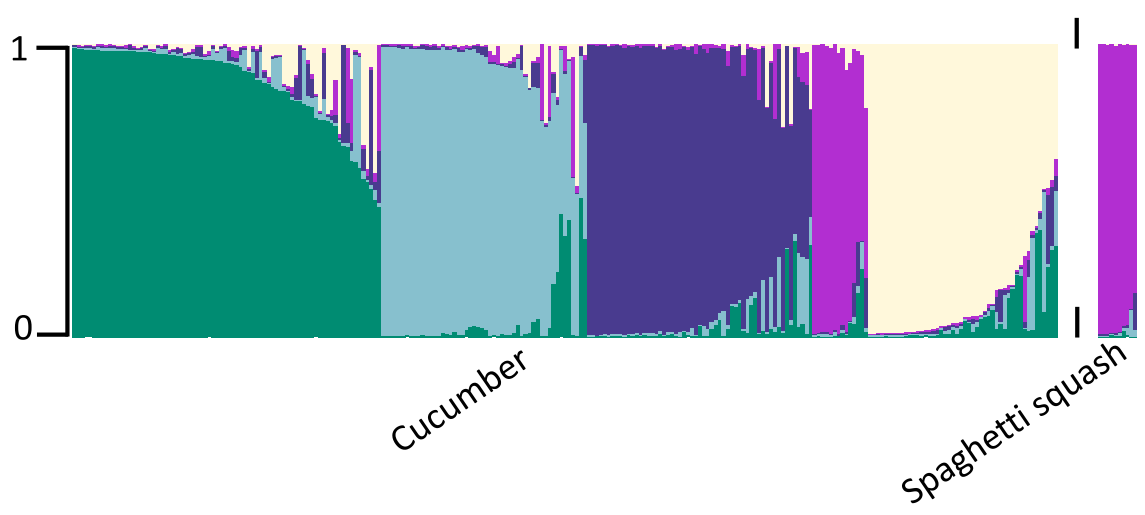

Fig. 5. Population structure of Pseudoperonospora cubensis isolates grouped by host. 
between Ontario and Michigan was explained by the grouping, suggesting other factors, such as isolate migration or host selection, are playing an important role in their differentiation. All of the populations detected in Ontario were present in Michigan, but a single unique Michigan cluster was detected at the first (August) sampling. Genetic diversity did not change in Michigan from August to September, but increased across the same time period in Ontario. This could suggest that diverse isolates might be moving from Michigan into Ontario during the growing season. The genetic diversity also varied greatly at the county and field level. The same fields sampled in Western Michigan had increased genetic diversity from August to September, while fields in Central and Eastern Michigan had reduced diversity. Fields in Ontario had a single sampling date. The highest genetic diversity was seen in Alymer (the sample site furthest to the west) and lowest genetic diversity was at the Mucks Crop Station (the sample site farthest to the east). While it is thought that isolates enter Michigan from southern states at the start of the season, the population structure of the state could change as the season progresses, if new isolates continue to appear from surrounding areas (Ojiambo and Holmes 2011). The unique Michigan cluster could be the result of inoculum entering the state, and future studies should include isolates from surrounding states to account for this possible migration route.

This work provides an initial evaluation of the changes in cucurbit downy mildew populations in Michigan within the growing season and a more in-depth analysis of differences in population structure with isolates from Ontario. Significant population structure was identified and changes in population structure varied by field, country, and sampling date. Future studies should evaluate more fields and sampling dates with higher resolution markers to better understand temporal population dynamics in cucurbit fields.

\section{ACKNOWLEDGMENTS}

We thank all the members of the Hausbeck lab for their valuable help. This work was supported by the Agricultural Research Fund, Pickle Packers International, Inc., Pickle and Pepper Research Committee of MSU, Fresh Vegetable Growers of Ontario, and APHIS Cooperative Agreement 13-8130-1254-CA. L. Quesada-Ocampo was supported by NIFA/USDA project NC02418.

\section{LITERATURE CITED}

Adams, M., Quesada-Ocampo, L. M., and Thornton, A. C. 2014. Evaluation of fungicides for control of downy mildew on cucumber, Kinston 2013. PDMR 8:V240.

Anonymous. 2012. CANSIM, Statistics Canada. http://www5.statcan.gc.ca/ cansim/home-accueil?lang=eng

Anonymous. 2013a. Michigan Agricultural Statistics Service. U.S. Department of Agriculture. http://www.nass.usda.gov/Statistics_by_State/Michigan/

Anonymous. 2013b. National Agricultural Statistics Service. U.S. Department of Agriculture. http://www.nass.usda.gov/

Barrès, B., Halkett, F., Dutech, C., Andrieux, A., Pinon, J., and Frey, P. 2008. Genetic structure of the poplar rust fungus Melampsora larici-populina: Evidence for isolation by distance in Europe and recent founder effects overseas. Infect. Genet. Evol. 8:577-587.

Call, A. D., Criswell, A. D., Weimer, T. C., Klosinska, U., and Kozik, E. U. 2012. Screening cucumber for resistance to downy mildew caused by Pseudoperonospora cubensis (Berk. and Curt.) Rostov. Crop Sci. 52: 577-592.

Calmin, G., Belbahri, L., and Lefort, F. 2007. Direct PCR for DNA barcoding in the genera Phytophthora and Pythium. Biotechnol. Biotechnol. Equip. 21:40.

Cespedes-Sanchez, M. C., Naegele, R. P., Kousik, C. S., and Hausbeck, M. K. 2014. Field response of cucurbit hosts to Pseudoperonospora cubensis in Michigan. Plant Dis. 99:676-682.

Cohen, Y., Rubin, A. E., Galperin, M., Ploch, S., Runge, F., and Thines, M. 2014. Seed Transmission of Pseudoperonospora cubensis. PLoS One 9:e109766.

Evanno, G., Regnaut, S., and Goudet, J. 2005. Detecting the number of clusters of individuals using the software structure: A simulation study. Mol. Ecol. 14:2611-2620.

Franck, P., and Timm, A. E. 2010. Population genetic structure of Cydia pomonella: A review and case study comparing spatiotemporal variation. J. Appl. Entomol. 134:191-200.
Granke, L. L., and Hausbeck, M. K. 2011. Dynamics of Pseudoperonospora cubensis sporangia in commercial cucurbit fields in Michigan. Plant Dis. 95:1392-1400.

Granke, L. L., Morrice, J. J., and Hausbeck, M. K. 2014. Relationships between airborne Pseudoperonospora cubensis sporangia, environmental conditions, and cucumber downy mildew severity. Plant Dis. 98:674-681.

Halkett, F., Coste, D., Rivas Platero, G. G., Zapater, M. F., Abadie, C., and Carlier, J. 2010. Genetic discontinuities and disequilibria in recently established populations of the plant pathogenic fungus Mycosphaerella fijiensis. Mol. Ecol. 19:3909-3923.

Hartl, D. L., and Clark, A. G. 2007. Principles of Population Genetics, 4th ed. Sinauer Associates, Sunderland, MA.

Hausbeck, M. K., and Linderman, S. D. 2014. Evaluation of fungicides for control of downy mildew of cucumber, 2013. PDMR 8:V304.

Holdsworth, W. L., Summers, C. F., Glos, M., Smart, C. D., and Mazourek, M. 2014. Development of downy mildew-resistant cucumbers for late-season production in the northeastern United States. HortScience 49:10-17.

Holmes, G., and Thomas, C. 2009. The history and re-emergence of cucurbit downy mildew. (Abstr.) Phytopathology 99(suppl.):S171.

Holmes, G., Wehner, T., and Thornton, A. 2006. An old enemy re-emerges: Downy mildew rears its ugly head on cucumber, impacting growers up and down the eastern US. Am. Veg. Grower 54:14-15.

Holmes, G. J, Ojambo, P. S., Hausbeck, M. K., Quesada-Ocampo, L., and Keinath, A. P. 2015. Resurgence of cucurbit downy mildew in the United States: A watershed event for research and extension. Plant Dis. 99: 428-441.

Kamvar, Z. N., Brooks, J., and Grünwald, N. J. 2015. Novel R tools for analysis of genome-wide population genetic data with emphasis on clonality. Front. Genet. 6:208

Kamvar, Z. N., Tabima, J. F., and Grünwald, N. J. 2014. Poppr: An R package for genetic analysis of populations with clonal, partially clonal, and/or sexual reproduction. PeerJ 2:e281.

Kanetis, L., Holmes, G. J., and Ojiambo, P. S. 2010. Survival of Pseudoperonospora cubensis sporangia exposed to solar radiation. Plant Pathol. 59:313-323.

Lara-Álvarez, I., Tharreau, D., Aguilar-Portero, M., and Castejón-Muñoz, M. 2010. Evidence for rapid changes in the population genetic structure of Magnaporthe oryzae in southern Spain. J. Phytopathol. 158:785-791.

Lebeda, A., and Cohen, Y. 2011. Cucurbit downy mildew (Pseudoperonospora cubensis)—biology, ecology, epidemiology, host-pathogen interaction and control. Eur. J. Plant Pathol. 129:157-192.

Lebeda, A., Pavelková, J., Sedláková, B., and Urban, J. 2013. Structure and temporal shifts in virulence of Pseudoperonospora cubensis populations in the Czech Republic: Variation in virulence of Pseudoperonospora cubensis. Plant Pathol. 62:336-345.

Lebeda, A., and Widrlechner, M. P. 2003. A set of Cucurbitaceae taxa for differentiation of Pseudoperonospora cubensis pathotypes. J. Plant Dis. Prot. 110:337.

Liu, K., and Muse, S. V. 2005. PowerMarker: An integrated analysis environment for genetic marker analysis. Bioinformatics 21:2128-2129.

McDonald, B. A., McDermott, J. M., Goodwin, S. B., and Allard, R. W. 1989. The population biology of host-pathogen interactions. Annu. Rev. Phytopathol. 27:77-94.

Moss, M. A. 1987. Resistance to metalaxyl in the Pseudoperonospora cubensis population causing downy mildew of cucumber in south Florida. Plant Dis. 71:1045.

Ojiambo, P. S., and Holmes, G. J. 2011. Spatiotemporal spread of cucurbit downy mildew in the eastern United States. Phytopathology 101:451-461.

Polat, I., Baysal, O., Mercati, F., Kitner, M., Cohen, Y., Lebeda, A., and Carimi, F. 2014. Characterization of Pseudoperonospora cubensis isolates from Europe and Asia using ISSR and SRAP molecular markers. Eur. J. Plant Pathol. 139:641-653.

Pritchard, J. K., Stephens, M., and Donnelly, P. 2000. Inference of population structure using multilocus genotype data. Genetics 155:945-959.

Quesada-Ocampo, L. M., Granke, L. L., Olsen, J., Gutting, H. C., Runge, F., Thines, M., Lebeda, A., and Hausbeck, M. K. 2012. The genetic structure of Pseudoperonospora cubensis populations. Plant Dis. 96:1459-1470.

R Development Core Team. 2012. R: A Language and Environment for Statistical Computing. R Foundation for Statistical Computing, Vienna, Austria.

Rivera, Y., Kretzer, A. M., and Horton, T. R. 2015. New microsatellite markers for the ectomycorrhizal fungus Pisolithus tinctorius sensu stricto reveal the genetic structure of US and Puerto Rican populations. Fungal Ecol. 13:1-9.

Runge, F., and Thines, M. 2009. A potential perennial host for Pseudoperonospora cubensis in temperate regions. Eur. J. Plant Pathol. 123:483-486.

Sarris, P., Abdelhalim, M., Kitner, M., Skandalis, N., Panopoulos, N., Doulis, A., and Lebeda, A. 2009. Molecular polymorphisms between populations of Pseudoperonospora cubensis from Greece and the Czech Republic and the phytopathological and phylogenetic implications. Plant Pathol. 58:933-943.

Savory, E. A., Granke, L. L., Quesada-Ocampo, L. M., Varbanova, M., Hausbeck, M. K., and Day, B. 2011. The cucurbit downy mildew pathogen Pseudoperonospora cubensis: Cucurbit downy mildew. Mol. Plant Pathol. 12:217-226. 
Sharma-Poudyal, D., Chen, X., and Rupp, R. A. 2014. Potential oversummering and overwintering regions for the wheat stripe rust pathogen in the contiguous United States. Int. J. Biometeorol. 58:987-997.

Tian, M., Win, J., Savory, E., Burkhardt, A., Held, M., Brandizzi, F., and Day, B. 2011. 454 Genome sequencing of Pseudoperonospora cubensis reveals effector proteins with a QXLR translocation motif. Mol. Plant-Microbe Interact. 24:543-553.

Urban, J., and Lebeda, A. 2007. Variation of fungicide resistance in Czech populations of Pseudoperonospora cubensis. J. Phytopathol. 155:143-151.

Wallace, E., Adams, M., Ivors, K., Ojiambo, P. S., and Quesada-Ocampo, L. M. 2014. First report of Pseudoperonospora cubensis causing downy mildew on Momordica balsamina and M. charantia in North Carolina. Plant Dis. 98:1279.
Wang, W., Yan, L., Meng, R., Zhao, J., Zhang, X., Han, X., and Ma, Z. 2014. Sensitivity to fluopicolide of wild type isolates and biological characteristics of fluopicolide-resistant mutants in Pseudoperonospora cubensis. Crop Prot. 55:119-126.

Xhaard, C., Barrès, B., Andrieux, A., Bousset, L., Halkett, F., and Frey, P. 2012. Disentangling the genetic origins of a plant pathogen during disease spread using an original molecular epidemiology approach. Mol. Ecol. 21: 2383-2398.

Zhang, X., Chen, Y., Zhang, Y., and Zhou, M. 2008. Occurrence and molecular characterization of azoxystrobin resistance in cucumber downy mildew in Shandong province of China. Phytoparasitica 36:136-143.

Zitter, T., Hopkins, D., and Thomas, C. 1996. Compendium of Cucurbit Diseases. The American Phytopathological Society, St. Paul, MN. 